\title{
Seasonal compensation of microbial production and respiration in a temperate sea
}

\author{
Pablo Serret ${ }^{1, *}$, Emilio Fernández ${ }^{2}$, Jorge A. Sostres ${ }^{1}$, Ricardo Anadón $^{1}$

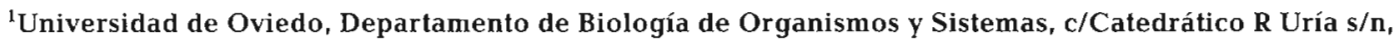 \\ 33071 Oviedo, Spain \\ ${ }^{2}$ Universidade de Vigo, Departamento de Ecoloxía e Bioloxía Animal, Campus Lagoas-Marcosende,
} 36200 Vigo, Spain

\begin{abstract}
Gross oxygen production (GP), dark respiration (DR) and net community production (NCP) were studied for 16 mo in the euphotic layer of 3 stations through the coastal transitional zone of the southern Bay of Biscay, and related to hydrographic and nutrient conditions, phytoplankton biomass and $\mathrm{C}$ incorporation. Microbial $\mathrm{O}_{2}$ fluxes exhibited seasonal patterns linked to the seasonal cycle of water column stratification and mixing, with positive NCP during the spring, negative throughout the summer and close to zero in winter. This pattern was altered at coastal regions, where productive periods were linked to coastal upwelling, whereas in winter persistent net heterotrophy was measured, presumably in relation to increases in organic matter discharge of continental origin. The comparison of $\mathrm{NCP}$ with $\mathrm{O}_{2}$ anomaly and $\mathrm{NO}_{3}$ concentration in the euphotic zone, the spatial and temporal scales studied and the prevalence of steady-state conditions offshore support the conclusion that the maintenance of summer heterotrophy in the region was based upon the consumption of the surplus of organic matter produced in spring. The uncoupling in the microbial auto- and heterotrophic metabolisms, based on the accumulation and delayed consumption of dissolved organic matter as a consequence of the processes controlling phytoplankton growth and microbial heterotrophic activity in temperate seas, would explain such a pattern. The close relationship observed between the seasonal variability in NCP and the magnitude of spring net production and predictions derived from the seasonal cycles of $\mathrm{O}_{2}$ anomaly in middle latitudes and atmospheric $\mathrm{O}_{2}$ led us to conclude that the seasonal compensation of production and respiration processes is a characteristic of the dynamics of the pelagic ecosystem, at least in coastal temperate seas. The implications of this conclusion are of great relevance for the interpretation of new production and the estimation of the trophic status of the ocean from direct measurements of plankton net production.
\end{abstract}

KEY WORDS: Production-respiration balance - Trophic dynamics · Phytoplankton - Bacteria $\cdot$ Oxygen anomaly Atmospheric oxygen

\section{INTRODUCTION}

Oceanic biota exerts a strong influence on the natural carbon cycle. Phytoplankton photosynthesis fixes $\mathrm{CO}_{2}$ in the upper euphotic zone of the oceans, which may be ultimately recycled within that layer or exported, in particulate or dissolved form, to greater depths. Sequestration of exported biogenic carbon at

\footnotetext{
- Present address: Centre for Coastal and Marine Sciences, Plymouth Marine Laboratory, Prospect Place, West Hoe, Plymouth PL1 3DH, United Kingdom.

E-mail: sipa@wpo.nerc.ac.uk
}

ocean depths (biological C pump) causes a decrease in surface seawater $\mathrm{CO}_{2}$ concentration, and eventually in atmospheric $\mathrm{CO}_{2}$ concentration. Although the importance of these processes in modifying global climate is well established over geological time scales (e.g. Holligan 1992), too many uncertainties exist over shorter (ecological) scales on the rates of relevant processes for the biological pump. Specifically, the paucity of respiration data has been suggested to be the reason why most marine carbon flux models fail to balance (Biddanda et al. 1994, Jahnke \& Craven 1995).

Net community production (NCP), defined as the difference between gross primary production and 
total community respiration, reflects the whole ecosystem dynamics better than the activity of primary producers or heterotrophs. Measured over adequate spatial and temporal scales, NCP may be equated to 'new' production, which represents the maximum exportable biomass to preserve the long-term integrity of the system (Eppley 1989, Quiñones \& Platt 1991), and allows calculation of the availability of a 'surplus' of primary production, and hence the determination of the potential fate of organic carbon produced in the euphotic zone.

Annual production/respiration (P/R) ratios reported in the literature for the euphotic zone of the ocean often result in net heterotrophic balances of pelagic biological activity, as predicted by some models (Smith \& Mackenzie 1987). This balance has been considered a consequence of the succession from a net autotrophic period during spring-winter to heterotrophic conditions in summer-autumn (see e.g. Rowe et al. 1986, review by Pomeroy \& Wiebe 1993, Griffith \& Pomeroy 1995). But, as stated by Pomeroy \& Wiebe (1993), 'a net heterotrophic water column is possible not only because of a temporary imbalance of photosynthesis and consumption but also because of organic inputs from rivers and atmospheric fallout'. The clarification of the relative contribution of these processes, and the scales over which they operate, to seasonal heterotrophy in temperate seas has been difficult to establish, mainly as a consequence of diverse limitations for interpreting the results of microbial production and respiration within this context. In some studies microbial respiration has not been directly measured, but estimated from bacterial growth through the use of diverse conversion rates (e.g. Rowe et al. 1986, Lignell et al. 1993, Krstulovic et al. 1995, Smith et al. 1995). However, the extrapolation from bacterial production to respiration is uncertain, making it difficult to determine the role of bacterial communitjes in carbon cycling (e.g. Jahnke \& Craven 1995). In other cases, the existence of auto- and heterotrophic phases has been deduced from independent studies performed within the different phases, and not directly observed over a complete time series including them all. In this regard, Pomeroy \& Wiebe (1993) highlighted that more than $2 / 3$ of 23 articles reviewed presented $P / R$ ratios $<1$, suggesting strong seasonal and regional shifts from auto- to heterotrophy, and a negative net balance for the ocean. Nevertheless, these authors noted that most of the reviewed data derived from short-term studies in non-steady-state systems, which can produce strong heterotrophic situations. Some studies on P/R succession have monitored organic matter production and consumption rates over time scales $>1$ yr (Blight et al. 1995, Smith \& Kemp 1995, Satta et al. 1996), however, these have been carried out in areas very close to the shore, in eutrophic conditions, or under strong tidal influence within estuaries or fjords, situations well away from steady state. Finally, some of the studies are restricted to surface $P / R$ measurements (e.g. Blight et al. 1995, Iriarte et al. 1996)

Besides the difficulties in determining the time scales for plankton trophic interactions, the recent detection of a seasonal cycle in the concentration of atmospheric oxygen (Keeling \& Shertz 1992, Bender et al. 1996) provides strong support for the idea of a temporal offset in the processes of synthesis and oxidation of organic matter in the sea (see reviews by Pomeroy \& Wiebe 1993 and Sherr \& Sherr 1996). A similar conclusion emerges from seasonal studies of the dissolved oxygen anomaly (the excess over saturation) in middle and high latitudes (see review by Najjar \& Keeling 1997). The lack of synchrony in the cycles of activity of heterotrophic and autotrophic microbes, suggested by ocean and atmospheric $\mathrm{O}_{2}$ cycles, would then establish the minimum temporal scale for carbon budget studies and, specifically, for the determination of the balance between production and respiration in order to quantify the 'trophic status' of the ocean.

The main objective of this paper is the study of the spatial and temporal scales of the linkage between microbial production and respiration processes in a temperate sea and, subsequently, the quantification of the net trophic balance over biogeochemically significant scales. A study of the spatial and temporal variability of phytoplankton biomass and $\mathrm{C}$ incorporation, and microbial $\mathrm{O}_{2}$ production and consumption was carried out in relation to hydrographic and chemical characteristics, throughout a temporal series of $16 \mathrm{mo}$ in a coastal middle latitude region. To the best of our knowledge this is the first report of microbial NCP obtained from true-depth measured oxygen fluxes in the whole euphotic zone of both shelf and oceanic waters, over a temporal scale $>1 \mathrm{yr}$.

\section{MATERIALS AND METHODS}

Sampling. A transect of 3 stations across the shelf off the northern Iberian coast (southern Bay of Biscay) was sampled monthly from January 1994 to June 1995 (Fig. 1). Sampling usually started at 10:00 h and ended by 17:00 h. At every station vertical profiles of conductivity and temperature were performed with a SBE2503 CTD. Photosynthetically available radiation (PAR) was measured with a submersible LiCOR spherical quantum sensor. Water samples for the determination of dissolved oxygen, inorganic nutrients and chl a concentrations were collected with 51 Niskin bottles from $2,10,20,30,40$ and $50 \mathrm{~m}$ at Stn 1, plus 75 and $100 \mathrm{~m}$ at Stn 2, and 150 and $200 \mathrm{~m}$ at Stn 3. Carbon incorpora- 


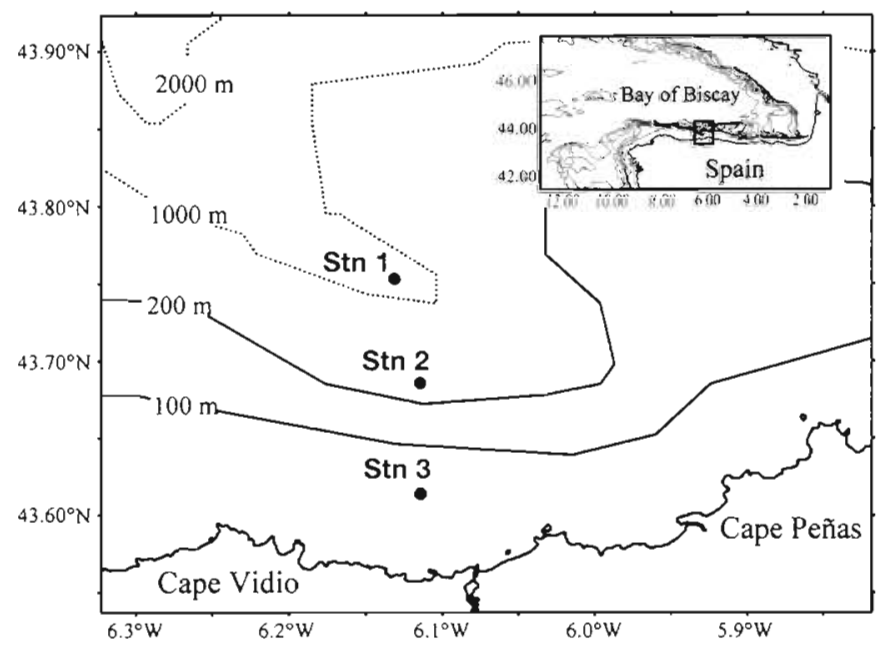

Fig. 1. Map of the region of study in the coastal transitional zone of the southern Bay of Biscay, showing the position of sampling stations

tion rates by phytoplankton were measured at 6 depths within the euphotic zone (corresponding to 100, 50, 20, 10,5 and $1 \%$ of surface irradiance, $I_{0}$ ). Rates of microbial $\mathrm{O}_{2}$ gross and net production and dark respiration (DR) were measured at 100, 20 and $1 \% I_{0}$. Seawater for $\mathrm{C}$ incorporation and $\mathrm{O}_{2}$ fluxes was immediately transferred into acid-washed polyethylene 51 carboys and transported to the laboratory, where it was kept at in situ $\left( \pm 1^{\circ} \mathrm{C}\right)$ temperature and in darkness until dawn, when incubations started.

Dissolved oxygen. A $125 \mathrm{~cm}^{3}$, gravimetrically calibrated, borosilicate bottle was carefully filled from every Niskin bottle by means of a silicone tube. Fixing and storage procedures, reagents and standardisation. followed the recommendations of Grasshoff et al. (1983). Dissolved oxygen concentration was measured by automated precision Winkler titration performed with a Metrohm 716 DMS Titrino, utilising a potentiometric end point (Oudot et al. 1988, Pomeroy et al. 1994, Pakulski et al. 1995). Aliquots of fixed samples were delivered by a $50 \mathrm{~cm}^{3}$ overflow pipette in order to improve the reproducibility of deliveries, as recommended by Pomeroy et al. (1994) for a stable platform.

Dissolved inorganic nutrients. Samples were collected in polystyrene tubes, frozen immediately after collection and stored at $-20^{\circ} \mathrm{C}$ until analysis. Concentrations of nitrate, nitrite, ammonia, phosphate and silicate were measured according to the methods described in Grasshoff et al. (1983).

Chl a. Dark, $250 \mathrm{~cm}^{3}$ polyethylene bottles were filled and transported at $4^{\circ} \mathrm{C}$ to the laboratory. Subsamples $\left(100 \mathrm{~cm}^{3}\right)$ were filtered onto $25 \mathrm{~mm}$ Whatman GF/F filters, which were frozen immediately. Chl a concentration was determined using a Turner Designs 10 fluoro- meter after extraction in $90 \%$ acetone for 24 h at $4^{\circ} \mathrm{C}$ (Strickland \& Parsons 1972).

Microplankton cell counts. At depths corresponding to 100,20 and $1 \%, I_{0}$ seawater samples were collected in $125 \mathrm{~cm}^{3}$ glass bottles containing ca $1 \mathrm{~cm}^{3}$ of Lugol's solution. Enumeration of organisms was carried out with an inverted microscope as described in Fernández et al. (1991)

Photosynthetic $\mathbf{C}$ incorporation. Seawater for the determination of $\mathrm{C}$ uptake by phytoplankton was collected at photic depths of ca 100,50,30,20,10,1\% $I_{0}$, and transferred to acid-washed $5 \mathrm{I}$ carboys. Three $70 \mathrm{ml}$ polycarbonate bottles were filled from each depth, inoculated with $370 \mathrm{Kbq}(10 \mu \mathrm{Ci})$ of $\mathrm{NaH}^{14} \mathrm{CO}_{3}$, and placed in outdoor water-cooled incubators. Once the incubation had finished, samples were filtered through Whatman GF/F filters under low vacuum pressure $(<100 \mathrm{~mm} \mathrm{Hg})$. Filters were immediately frozen and stored at $-20^{\circ} \mathrm{C}$ until later analysis. Samples were processed for determination of $\mathrm{C}$ incorporation into macromolecules (proteins, carbohydrates, lipids and low molecular weight metabolites), following the method described in Marañón et al. (1995). Total primary production was calculated as the sum of $\mathrm{C}$ incorporated into each fraction. The sum of ${ }^{14} \mathrm{C}$ activity in the 4 obtained metabolic fractions accounts for 90 to $104 \%$ of total activity as measured in parallel non-fractionated samples (Marañón et al. 1995). Samples were counted in a liquid scintillation Packard counter, after addition of Optiphase HI-safe scintillation liquid. Quenching was corrected by internal standard.

Oxygen production and consumption. $\mathrm{O}_{2}$ production and consumption rates were determined by lightand dark-bottle incubations. Seawater was transferred from every $5 \mathrm{dm}^{3}$ carboy (corresponding to photic depths of 100,20 and $1 \% I_{0}$ ) to 4 light and 8 dark acidcleaned, individually calibrated, $125 \mathrm{~cm}^{3}$ nominal volume borosilicate glass bottles. Bottles were filled using silicone tubing, overflowing $>250 \mathrm{~cm}^{3}$. An initial set of 4 dark bottles was fixed immediately for initial oxygen concentration, the remainder being placed in the same incubator as $\mathrm{C}$ uptake bottles. $\mathrm{O}_{2}$ and ${ }^{14} \mathrm{C}$ incubations always ran simultaneously. Incubation temperature was within $\pm 1^{\circ} \mathrm{C}$ in situ temperature. The remaining 4 dark bottles were placed in dense black plastic bags, while every set of 4 light bottles was placed in neutral density mesh bags simulating the light intensity at the sampled depth. Incubations started at dawn and lasted $24 \pm 0.5$ h over a diel cycle with natural light. NCP and DR were estimated as the change in oxygen concentration in the light and dark bottles, respectively, after incubation. Gross oxygen production (GP) was estimated as the result of NCP minus DR. Dissolved oxygen concentration was determined following the method described above. 


\section{RESULTS}

\section{Physical and chemical characteristics}

The vertical distribution of temperature and sigma-t through the period of study at the 3 sampling stations is shown in Fig. 2. A marked seasonal pattern driven by spring surface heating and winter mixing is evident. This general pattern, characteristic of temperate seas, was modified by several episodic hydrodynamic events, mainly slope currents and wind-driven coastal upwellings, a complete description of which is given elsewhere (Botas et al. 1990, Fernández et al. 1993). Fig. 2 also presents the spatio-temporal variation in nutrient concentration and oxygen saturation at the 3 sampling stations. Given the high correlation found between nitrate and phosphate $(r=0.61$ (Stn 1), 0.82 (Stn 2) and 0.75 (Stn 3), p < 0.005) and nitrate and silicate concentrations $(r=0.70$ (Stn 1), 0.85 (Stn 2) and 0.92 (Stn 3); $p<0.005$ ), only nitrate data are shown. Nutrient concentration and oxygen saturation were inversely related $(r=-0.44,-0.65$ and -0.73 in $\operatorname{Stn} 1$, Stn 2 and Stn 3, respectively; $p<0.01$ ) and both followed seasonal trends strongly related to the temporal evolution of water-column stability.

In March and April 1994, although the thermal field was typical of winter $\left(<13^{\circ} \mathrm{C}\right.$ throughout the water col- umn), sigma-t distributions show transient stratifications, after the intrusion of high salinity water onto the shelf, which resulted in the concurrence of high-salinity water $(>35.60)$ at intermediate depths, together with low-salinity surface water. These intrusions, which generate clear thermohaline fronts separating coastal from oceanic waters (Fernández et al. 1993), are a consequence of warm, high-salinity slope currents flowing along the Atlantic and northern Iberian coast with decreasing thickness (e.g. Pingree \& Le Cann 1990). The situations of transient vertical stability they generate are related to the development of spring phytoplankton blooms prior to the settlement of thermal stratification, as could be observed offshore in April 1994 when the signature of a bloom is clear in the marked decrease in $\mathrm{NO}_{3}$ concentration and the concurrent increase in $\mathrm{O}_{2}$ saturation at $\mathrm{Stn} 2$ and $\mathrm{Stn} 3$.

In both shelf and oceanic waters a thermocline developed from May 1994, separating a surface nutrient-depleted layer $\left(<1 \mu \mathrm{mol} \mathrm{NO} \mathrm{Ng}^{-1},<0.2 \mu \mathrm{mol} \mathrm{PO}_{4}\right.$ $\mathrm{kg}^{-1},<1.5 \mu \mathrm{mol} \mathrm{Si} \mathrm{kg}^{-1}$ ) from bottom, nutrient-rich waters. A coastal upwelling of cold, nutrient-rich and oxygen-impoverished deep water took place in June 1994, when summer vertical stratification prevailed offshore. During the summer, stratification was more intense and the surface mixed layer deepened offshore and, accordingly, nutrient depletion was more severe

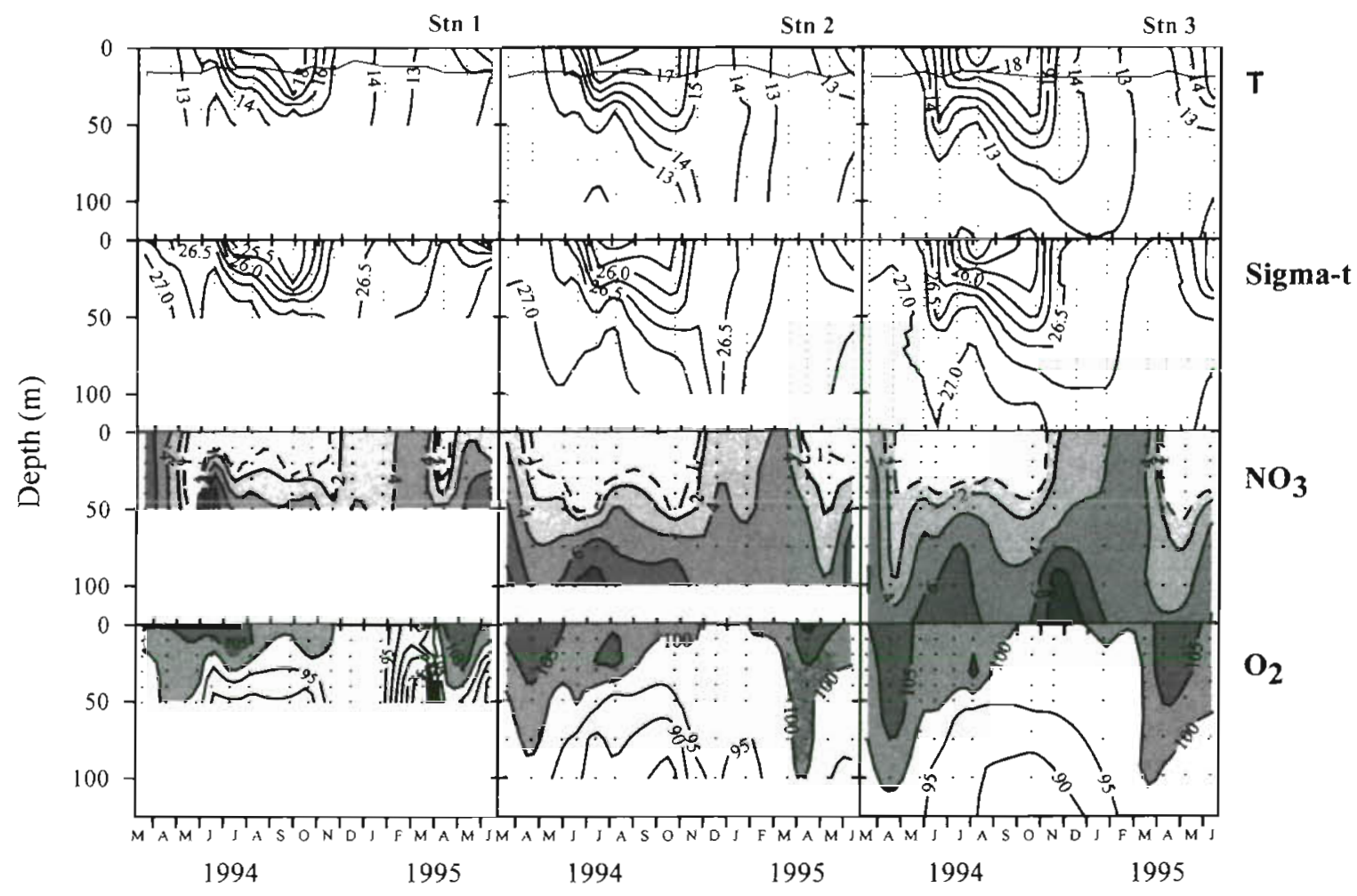

Fig. 2. Spatio-temporal distribution of temperature $\left(\mathrm{T},{ }^{\circ} \mathrm{C}\right.$ ), sigma-t, nitrate concentration ( $\mu \mathrm{mol} \mathrm{kg}^{-1}$ ) and percentage of oxygen saturation at the 3 sampled stations. The depth of the euphotic layer $\left(1 \% I_{0}\right)$ is superimposed on the temperature contours 
in oceanic than in coastal waters. The thickness of the surface oxygen-saturated layer progressively decreased during the summer, while below the relatively mixed surface layer low values of oxygen saturation were observed. From June onwards, subsurface (25 to $30 \mathrm{~m}$ depth) maxima of dissolved oxygen concentration developed at Stn 2 and Stn 3, coinciding with the deepest part of the nutrient-depleted layer.

The summer pycnocline deepened between September and October and finally vanished in OctoberNovember. Consequently the euphotic zone nutrient content increased after mixing with deeper water. After November, thorough mixing reset winter conditions. The water column cooled to $<14^{\circ} \mathrm{C}$, and a completely mixed water column was found in coastal waters, while in oceanic waters the surface mixed layer extended to ca $100 \mathrm{~m}$ depth. The concentration of dissolved inorganic nutrients in the surface mixed layer was high, and typical values of $>3 \mu \mathrm{mol} \mathrm{NO} \mathrm{Ng}^{-1}$, $>0.3 \mu \mathrm{mol} \mathrm{PO}_{4} \mathrm{~kg}^{-1}$ and $>2 \mu \mathrm{mol} \mathrm{SiO}_{4} \mathrm{~kg}^{-1}$ were measured throughout the water column, both at shelf and oceanic stations. Oxygen concentration was slightly below saturation, especially in coastal waters.

In April 1995 a new coastal upwelling pulse took place, in this case under mixed conditions. Although an increase in deep nitrate concentration was observed towards the coast, very low concentration of $\mathrm{NO}_{3}$ was measured in surface coastal waters $\left(<0.2 \mathrm{mmol} \mathrm{NO}_{3}\right.$ $\mathrm{kg}^{-1}$ ). Nevertheless, a marked coastal increase in silicate and phosphate concentrations (>1.2 $\mu \mathrm{mol} \mathrm{kg} \mathrm{kg}^{-1}$ ) (data not shown), as well as oxygen saturation levels, traced the advective process, suggesting that active phytoplankton growth occurred prior to sampling in surface coastal waters. Moreover, the offshore increase of surface $\mathrm{O}_{2}$ saturation, and the deepening of both nutrient exhaustion and $\mathrm{O}_{2}$ supersaturation show the movement of surface coastal water $\left(\mathrm{O}_{2}\right.$-enriched and $\mathrm{NO}_{3}$-depleted) and its convergence at the shelf-break front.
In March 1995, after several storms which occurred in February, very low salinity $(<35.00)$ was measured in surface water at $\mathrm{Stn} 1$, thus provoking a strong haline stratification. No effect on $\mathrm{NO}_{3}$ concentration was observed, but very low $\mathrm{O}_{2}$ saturation (<85\%) prevailed at all depths.

\section{Phytoplankton biomass and photosynthetic carbon incorporation}

Spatio-temporal distributions of chl a concentration and $C$ incorporation (Fig. 3) showed a similar trend to that of oxygen saturation.

In April 1994 a marked increase in phytoplankton biomass paralleled sharp changes in nutrient content and $\mathrm{O}_{2}$ saturation, all suggesting that a spring phytoplankton bloom had developed offshore (Stns 2 and 3) between March and April 1994. The sinking at the outermost station of elevated phytoplankton biomass is clear from the deep chl a maximum and the high chl a concentration ( $>1 \mathrm{mg} \mathrm{m}^{-3}$ ) measured down to $100 \mathrm{~m}$ depth.

After the spring bloom, when surface nitrate content had been markedly reduced, phytoplankton biomass decreased and deep chl a maxima (DCM) developed. This feature was already evident in May 1994, when a vertical gradient $>1^{\circ} \mathrm{C}$ developed in the upper $50 \mathrm{~m}$. The upwelling in June 1994 altered the development of the summer DCM at the coastal station. In the relatively mixed and nutrient-enriched waters a marked increase in phytoplankton biomass was observed. Chl a concentration $>7 \mathrm{mg} \mathrm{m}^{-3}$ was measured in the upper $20 \mathrm{~m}$, and the euphotic zone integrated concentration amounted to $>240 \mathrm{mg} \mathrm{m}^{-2}$. Diatoms accounted for ca $70 \%$ of phytoplankton abundance. After the upwelling, thermal stratification returned and $<0.5 \mathrm{mg}$ chl $a \mathrm{~m}^{-3}$ was measured in the nutrient-depleted surface layer during summer, while at depths between 20 and $40 \mathrm{~m}$ chl a concentration was $>1.5 \mathrm{mg}$ chl a m $\mathrm{m}^{-3}$.

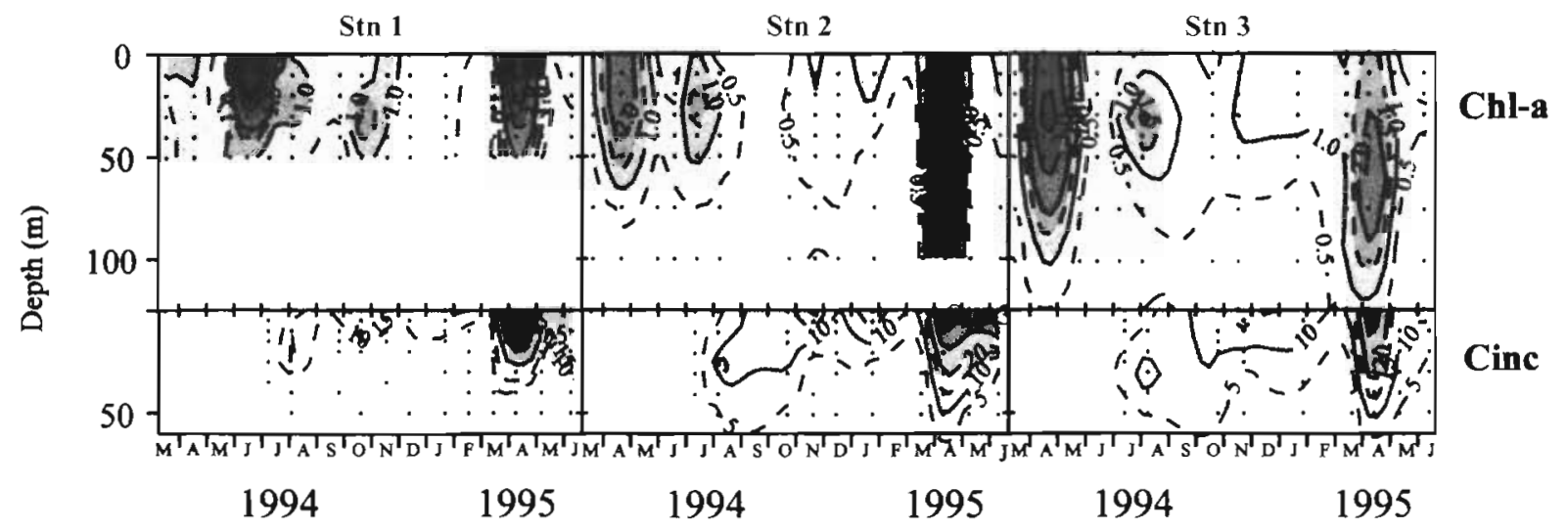

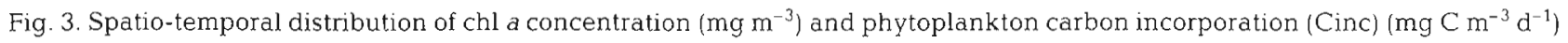
at the 3 sampled stations 
C incorporation was low in the surface layer, especially offshore, increasing in the DCM $>10 \mathrm{mg} \mathrm{C} \mathrm{m}^{-3} \mathrm{~d}^{-1}$ at $\left.10 \% I_{0}\right)$. Ciliates were relatively abundant in the DCM, while diatoms and dinoflagellate densities were low.

The DCM disappeared when wind mixing deepened the surface mixed layer (September 1994 Stn 1; October 1994 Stn 2 and Stn 3). Vertically homogeneous concentrations of ca $0.7 \mathrm{mg} \mathrm{chl} \mathrm{a} \mathrm{m} \mathrm{m}^{-3}$ were observed in the upper $30 \mathrm{~m}$ of the water column. Coinciding with the autumn increase in $\mathrm{NO}_{3}$ content after the vanishing of the pycnocline (October $1994 \mathrm{Stn} 1$; November 1994 Stn 2 and Stn 3), chl a concentration and C incorporation increased at all the stations.

In winter, during the phases of vertical homogeneity of the water column, low chl a concentration $k 1 \mathrm{mg}$ $\mathrm{m}^{-3}$ ) and $\mathrm{C}$ incorporation rates were registered, both exhibiting weak surface maxima. Relatively high abundances of flagellates ( 70 cells $\mathrm{ml}^{-1}$ ) and ciliates (>8 cells $\mathrm{ml}^{-1}$ ) were observed at Stn 1. During slope current intrusions (March and April 1994, January 1995) increases of phytoplankton biomass and $C$ incorporation were found at the surface of areas with relative vertical stability.

As in 1994 (see above), the 1995 spring phytoplankton bloom was not related to thermal stratification but to coastal upwelling. Very high chl a concentration and primary production were measured in the surface, $\mathrm{NO}_{3}$-impoverished and $\mathrm{O}_{2}$-enriched waters of the coastal region, while offshore sinking of biomass and a decrease in primary production were evident.

\section{Oxygen fluxes}

Figs. 4 to 6 show the temporal evolution of dark respiration (DR), and gross (GP) and net community (NCP) production of oxygen at the 3 sampled depths within the euphotic layer of the 3 stations. The seasonal trend of GP almost perfectly matched that of $C$ incorporation $(r=0.98,0.90$ and 0.81 for every depth of Stn 1, Stn 2 and Stn 3, respectively; $p<0.005$ in all cases). Although DR was not directly related to chl a concentration or $\mathrm{C}$ incorporation rates, both DR and NCP exhibited marked seasonal patterns coupled to the variation in biomass and activity of phytoplankton described above. As with $\mathrm{C}$ incorporation, the greatest seasonal variation in oxygen fluxes was observed in coastal waters, especially at the surface.

In April 1994, relatively high rates of GP were measured at Stn 2 and Stn 3 in samples from 100 and $20 \%$ $I_{0}$. These were related to the observed increase in phytoplankton biomass more than to an increase in activity, since GP rates normalised to chl a concentration were very low (ca $2 \mathrm{mmol} \mathrm{O}_{2} \mathrm{mg}^{-1} \mathrm{chl} \mathrm{a} \mathrm{d} \mathrm{d}^{-1}$ at Stn 2; $0.8 \mathrm{mmol} \mathrm{O}_{2} \mathrm{mg}^{-1} \mathrm{chl} a \mathrm{~d}^{-1}$ at $\left.\mathrm{Stn} 3\right)$. Despite the large increase of phytoplankton biomass, low DR rates were measured at Stn 2 . Hence at this station very high NCP rates were registered both at the surface and at $20 \% I_{0}$ (ca $4 \mathrm{mmol} \mathrm{O}_{2} \mathrm{~m}^{-3} \mathrm{~d}^{-1}$ ), and even samples from $1 \% I_{0}$ presented positive values of NCP. At Stn 3, where sinking of phytoplankton biomass occurred, DR was higher, and hence lower NCP rates were measured. At $1 \% I_{0}$ depth, coinciding with the highest chl a concentration, negative NCP rates were found.

After the spring bloom, during the formation of the DCM (May 1994 at Stn 2 and Stn 3), high GP and NCP rates were recorded in the upper limit of the DCM, at $20 \% I_{0}$. Relatively high values were also recorded from surface samples, while below the DCM, at the depth of $1 \% I_{0}$, both GP and DR were very low, and NCP was nearly zero. A large increase in GP was recorded in June 1994 in the upwelled waters of the coastal station (Stn 1), mainly at the surface (ca $20 \mathrm{mmol} \mathrm{O} \mathrm{m}^{-3} \mathrm{~d}^{-1}$ ). Concurrently, a marked decrease of DR occurred at all depths, despite the elevated phytoplankton biomass and activity. Consequently, NCP was very high throughout the euphotic zone of the coastal region. Offshore lower GP rates and higher DR rates were measured, especially in surface waters where NCP was negligible. Positive NCP was only measured off-
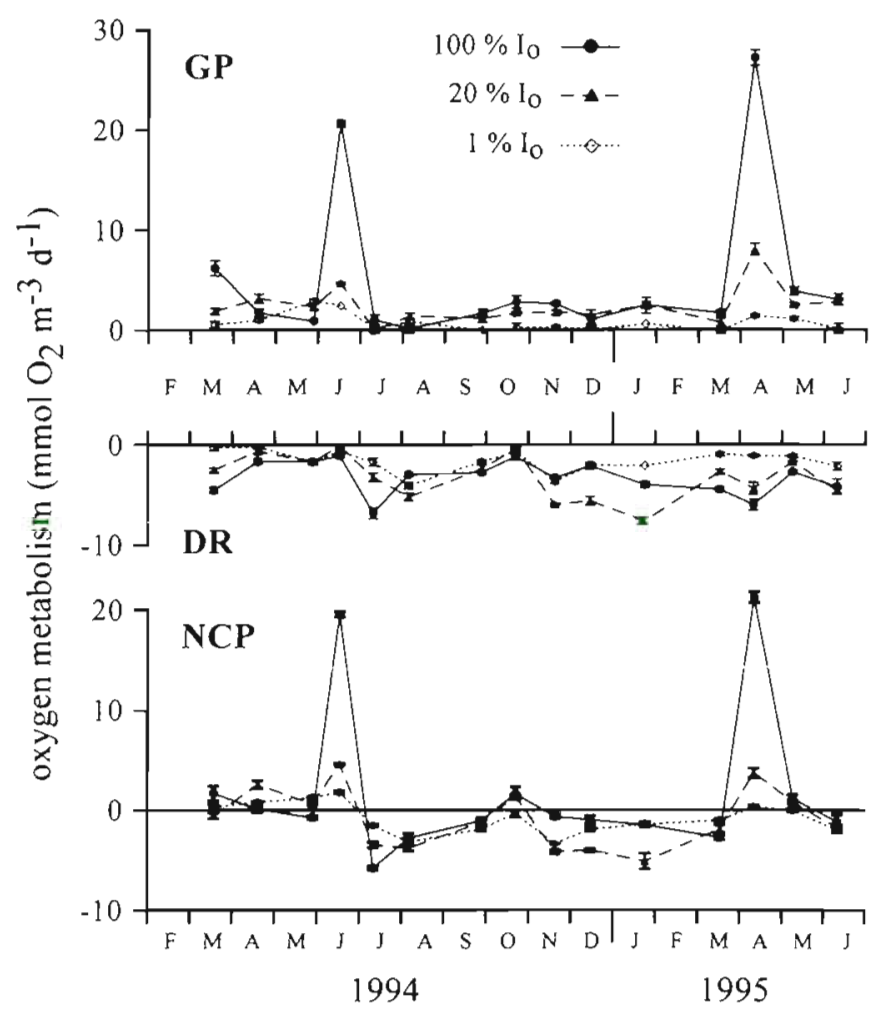

Fig. 4. Temporal variation in gross production (GP), dark respiration (DR) and net community production (NCP) rates at the 3 sampled depths $\left(100,20\right.$ and $\left.1 \% I_{0}\right)$ at $\operatorname{Stn} 1$. The average \pm 1 SE of 4 replicates are shown 


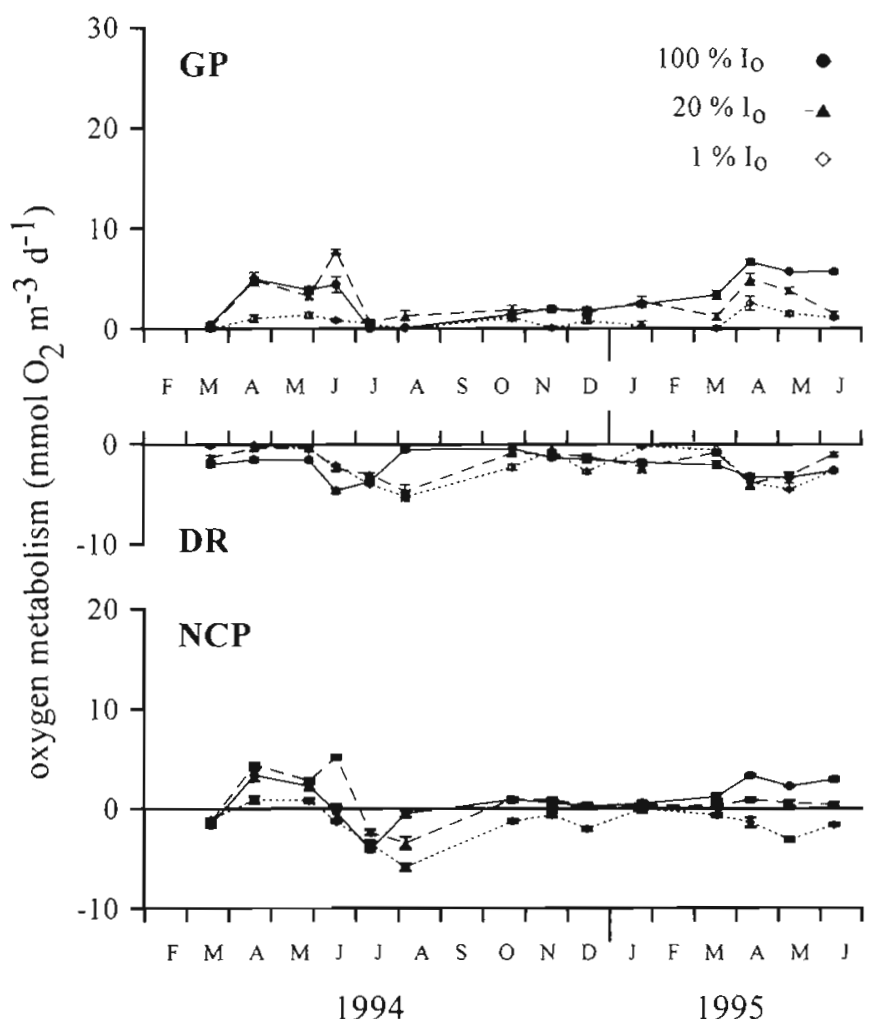
piration (DR) and net community production (NCP) rates at the 3 sampled depths $\left(100,20\right.$ and $\left.1 \% I_{0}\right)$ at Stn 2 . The average $\pm 1 \mathrm{SE}$ of 4 replicates are shown

shore at $20 \% I_{0}$ depth. After the upwelling, GP decreased and DR increased throughout the study area. When the summer DCM was well established (July 1994 at Stns 2 and 3; August 1994 at Stns 1, 2 and 3) very low GP rates were recorded at all depths. Surface GP was negligible and only ca $1 \mathrm{mmol} \mathrm{O}_{2} \mathrm{~m}^{-3} \mathrm{~d}^{-1}$ was measured at $20 \% I_{0}$, in the upper layer of the DCM. DR was always very high and hence negative NCP was recorded throughout the summer, even at the DCM.

In October-November 1994, coinciding with the deepening of the pycnocline, phytoplankton blooms developed (see Figs. $2 \& 3$ ) and relative increases of GP rates were observed at the surface and $20 \% I_{0}$ depth at every station. Nevertheless, the marked decrease found at all depths in DR rates (reaching minima annual values), both in coastal and offshore waters, resulted in an increase of NCP to positive values at 100 and $20 \% I_{0}$ depths.

During winter mixing periods (Dec 1994 Stns 1 and 2; March 1995 Stns 2 and 3), when phytoplankton biomass and $\mathrm{C}$ uptake were low, relatively low rates of GP were recorded throughout the region of study (ca $2 \mathrm{mmol} \mathrm{O}_{2} \mathrm{~m}^{-3} \mathrm{~d}^{-1}$ at surface and 20\% $I_{0}$ samples; negligible values at depths corresponding to $1 \% I_{0}$ ). DR, however, exhibited marked differences between coastal and offshore waters. At Stn 2 and Stn 3 rates of DR were low and balanced GP both at the surface and $20 \% I_{0}$; negative values of NCP were only found in samples from $1 \% I_{0}$. At the coastal station, in contrast, high DR rates produced large negative values of NCP in the euphotic zone during the winter, even at the surface. As occurred with chl a concentration and C incorporation rates, slope current intrusions were related during this period to increases in GP and especially DR in the vertically stratified waters (see Stn 1 in March 1994, and Stn 3 in January 1995)

The upwelling during April 1995 gave rise to a marked increase in GP rates at Stn 1, especially at the surface, as during the June 1994 upwelling event. In contrast to June 1994, in April 1995 a clear increase of DR was observed both in coastal and offshore waters, the spatial distribution of DR matching that of chl a concentration (see Fig. 4). This general increase of DR rates following the offshore sinking of phytoplankton biomass and oxygen enriched waters, together with nitrate depletion in coastal surface waters, suggests that the situation observed in April 1995 corresponded to an aged upwelling. Moreover, DR spatial distribution in April 1995 was very similar to that observed in July 1994, 1 mo after the upwelling of June 1994

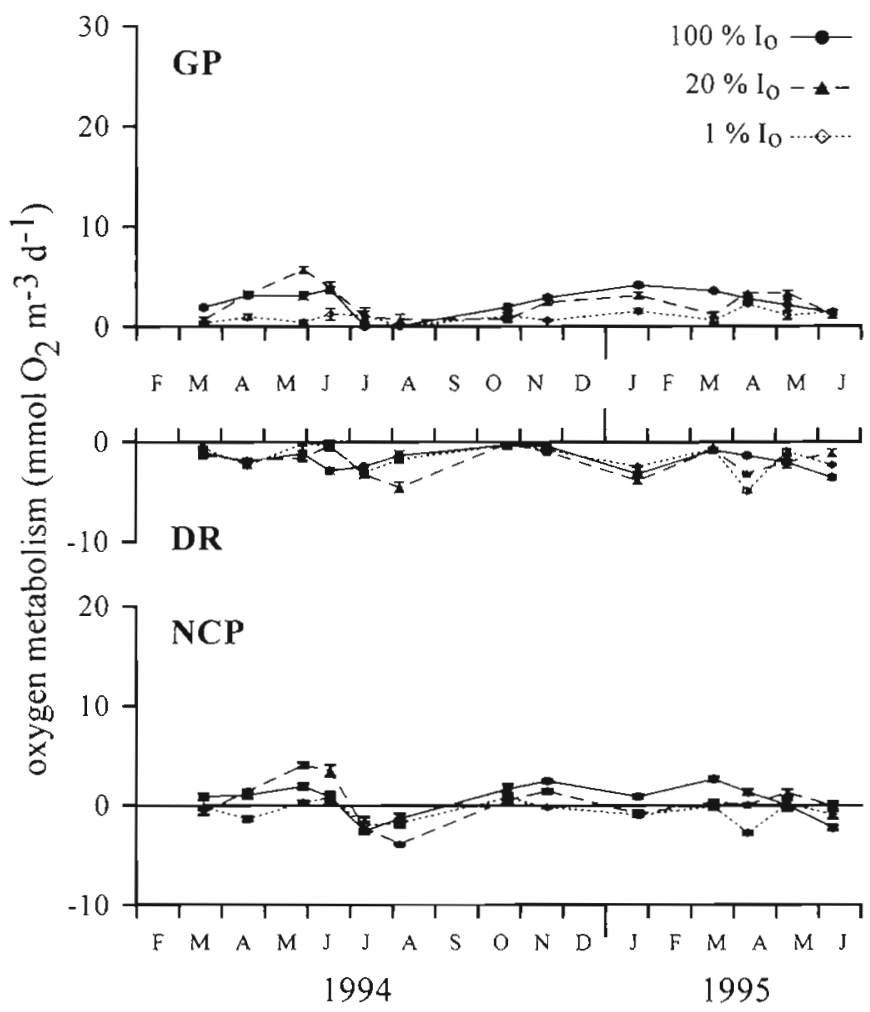

Fig. 6. Temporal variation in gross production (GP), dark respiration (DR) and net community production (NCP) rates at the 3 sampled depths $\left(100,20\right.$ and $\left.1 \% I_{0}\right)$ at $\operatorname{Stn} 3$. The average $\pm 1 \mathrm{SE}$ of 4 replicates are shown 


\section{Euphotic zone integrated oxygen fluxes}

When GP, DR and NCP rates were integrated throughout the euphotic zone (GPeu, DReu and NCPeu, Fig. 7) at every station, a very similar pattern emerged for the first 9 mo of sampling, characterised by positive NCPeu during spring, followed by a net heterotrophic balance throughout the summer, until autumn phytoplankton blooms. During winter, however, marked differences were found between coastal and offshore waters. While near zero net balances were observed at Stn 2 and Stn 3, very high DR rates were measured at $S t n 1$, resulting in negative values of NCPeu.

In April 1994, similar values of GPeu were obtained at both offshore stations where the spring phytoplankton bloom occurred. However, while very low DReu rates at $\operatorname{Stn} 2\left(-22 \mathrm{mmol} \mathrm{O}_{2} \mathrm{~m}^{-2} \mathrm{~d}^{-1}\right)$ gave rise to very high positive NCPeu, at the outermost station (Stn 3), where the sinking of elevated phytoplankton biomass was evident, higher DReu rates $\left(-102 \mathrm{mmol} \mathrm{O}_{2} \mathrm{~m}^{-2} \mathrm{~d}^{-1}\right)$
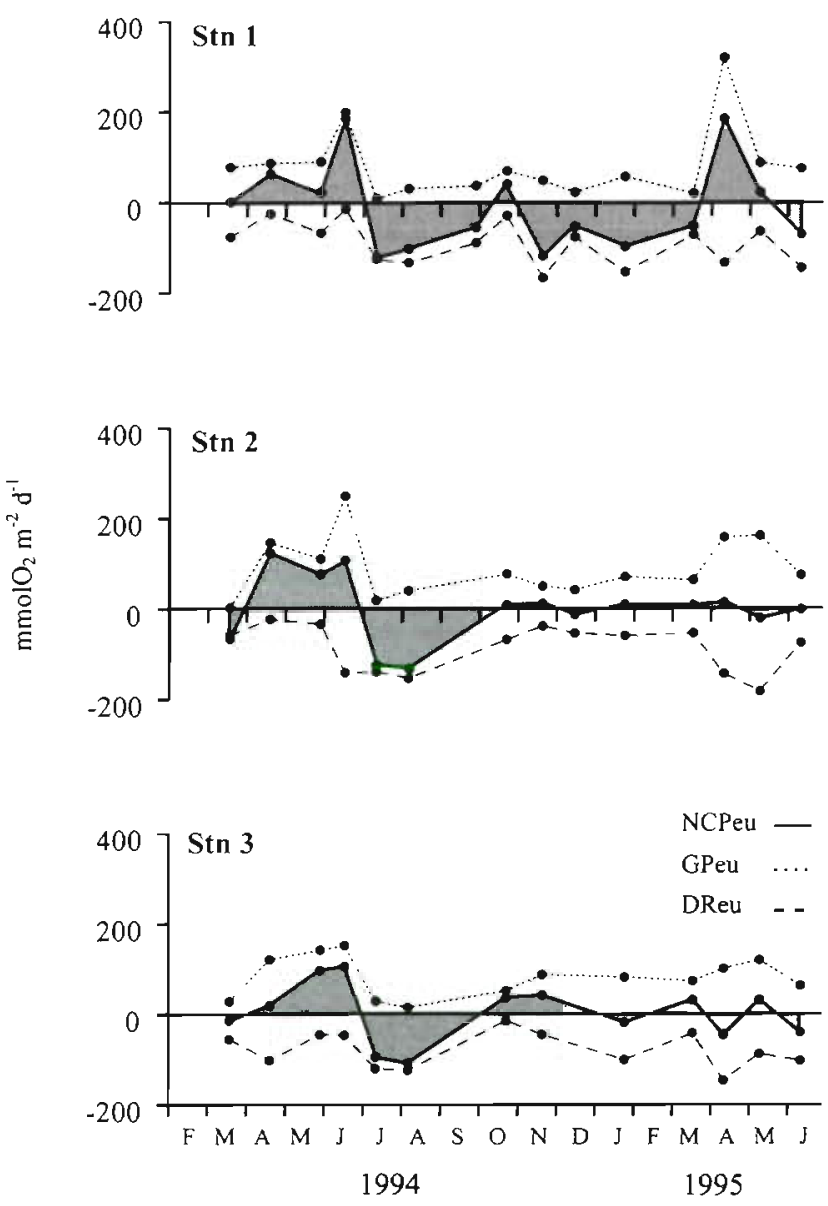

Fig. 7. Temporal variation in euphotic zone integrated rates of net community production (NCPeu), gross production (GPeu) and dark respiration (DReu) at the 3 sampled stations compensated the elevated GPeu. Positive NCPeu persisted, especially offshore, until the end of the spring.

Elevated GPeu and low DReu prevailed offshore while the DCM developed (May 1994). During the coastal upwelling in June 1995 a marked increase in GPeu and a sharp decrease in DReu (reaching the minimum value of the whole period of study) gave rise to a very high value of NCPeu at Stn 1. Although DReu increased offshore, high positive NCPeu was also measured at Stn 2 and Stn 3. During summer very low GPeu rates were recorded at the 3 sampled stations; however, despite the low phytoplankton biomass and primary production, very high DReu rates were found. Hence elevated heterotrophic balances in the euphotic zone ( $\mathrm{ca}-100 \mathrm{mmol} \mathrm{O}_{2} \mathrm{~m}^{-2} \mathrm{~d}^{-1}$ ) of the region of study prevailed throughout the summer. This was the only period of sustained intense net heterotrophy at offshore waters, while similar negative NCPeu was obtained at coastal waters during the winter.

Autumn blooms (October-November 1994) were characterised by marked decreases in DReu and relative increases in GPeu, thus giving rise to positive balances in the euphotic zone of all the stations during this period.

During winter mixing periods, relatively low GPeu and DReu were measured offshore, giving rise to a NCPeu near zero. At the coastal region, although GPeu was also low, high DReu rates produced large negative values of NCPeu.

A marked increase in GPeu was observed, especially towards the coast, during the phytoplankton bloom associated with an upwelling pulse in April 1995. Contrary to the sharp decrease in DR rates observed in June 1994, a clear increase occurred in April 1995. During the latter event, and paralleling the offshore sinking of phytoplankton biomass, high DReu was also measured offshore, and negative NCPeu occurred at the outermost station.

\section{Annual fluxes of oxygen}

Fig. 8 presents the annual integration of production and consumption of oxygen in the euphotic zone of the 3 sampled stations. Given that more than 1 complete year was sampled, every (5) possible integral of 12 mo has been calculated. Taking into account the possibility of net heterotrophic periods being sustained by the excess production of previous autotrophic phases, those integrals in which a complete seasonal series including the spring productive phase followed by the subsequent heterotrophic phases (i.e. only the first 2 periods of 12 mo of our cycle) are highlighted.

Despite the different contribution to annual GPeu of the diverse productive processes observed in coastal 


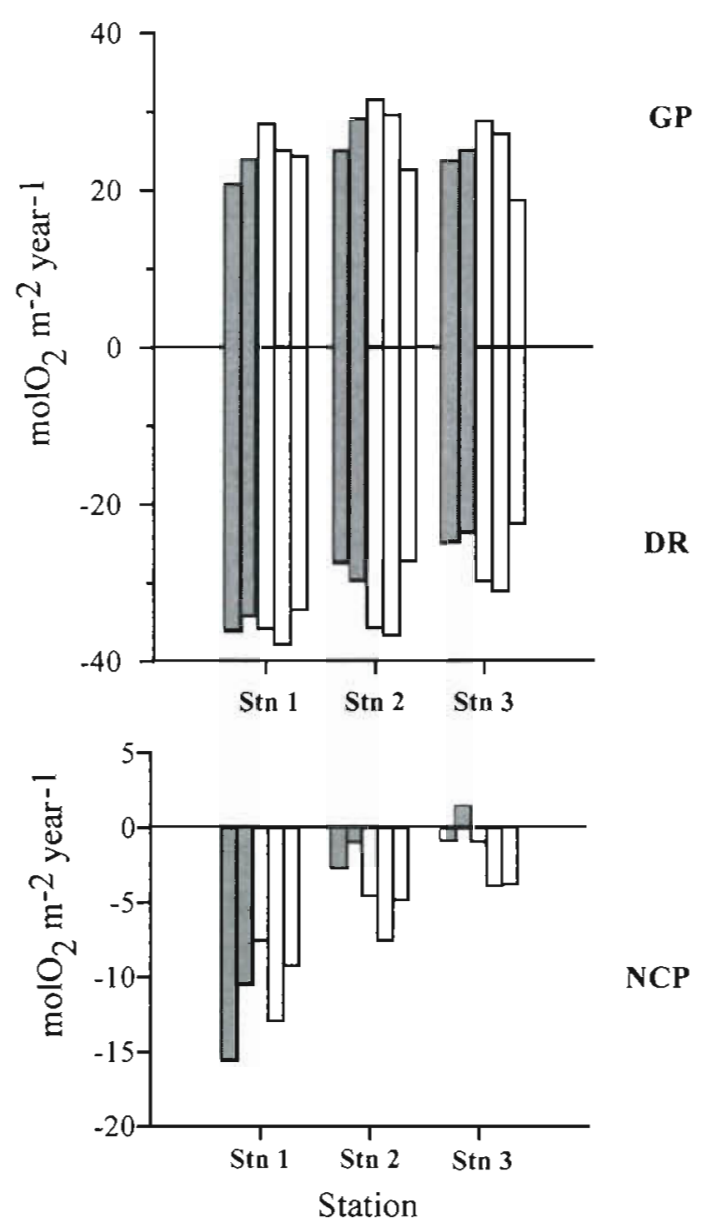

Fig. 8. Annually integrated rates of gross production (GP), dark respiration (DR) and net community production (NCP) in the euphotic zone at the 3 sampled stations. Values corresponding to the 5 successive periods of 12 mo are shown. Filled bars: first 2 integrals, which are the only ones starting in spring (see text for details)

and oceanic waters (phytoplankton blooms associated with coastal upwellings, spring and autumn blooms), annual GPeu was very similar at the 3 studied stations. Conversely, annual DReu increased towards the coast as a result of the marked differences found between coastal and oceanic waters in the winter DR rates (see Fig. 7). Consequently, these differences in DReu are the cause of the spatial pattern in annual NCPeu observed. This variable was negative at the coastal station, while an offshore trend towards $P / R$ equilibrium was observed.

\section{Trophic significance of oxygen $P / R$ balances}

Although the seasonal evolution of $P$ and $R$ rates in relation to hydrographic conditions, nutrient levels and phytoplankton biomass and activity, can be easily interpreted from an ecological perspective, the significance of temporal variability of depth-integrated rates is not so clear, especially in a biogeochemical context. This uncertainty arises from differences between the scales of the measured variables (daily rates of $P$ and $R$ ) and the time span over which the inferred trophic status may apply. The observed annual cycle of $\mathrm{P}$ and $\mathrm{R}$ is by no means continuous, but a result of a series of relatively independent processes (e.g. upwellings, thermal or haline vertical stratifications, etc.), and it is not easy to ensure that every significant event has been sampled. The seasonal P/R cycles shown in Figs. 4 to 6 suggest that the time scales of variability in community metabolism may be shorter than the period of sampling. Hence, although auto-heterotrophy transitions are frequently observed between 2 consecutive samples, there is a lack of information on how these transitions developed. In addition, advection may modify the interpretation of $P / R$ balances, since changes in $P / R$ may be due to the departure from steady-state conditions rather than microbial physiology. Hence, before undertaking the interpretation of seasonal and annual $P / R$ balances, it should be confirmed that the measured oxygen fluxes are an adequate representation of the annual cycle of microbial production and consumption of organic matter.

Under steady-state conditions, oxygen saturation in seawater is directly dependent upon the balance between photosynthesis and total respiration, i.e. NCP. Thus a comparison of $\mathrm{O}_{2}$ saturation and NCP may indicate the extent to which steady-state conditions prevailed. Moreover, oxygen saturation summarises the recent history of water column net metabolism, and the comparison of NCPeu cycles and oxygen saturation will provide insight into the accuracy of using monthly measured NCP to estimate the annual cycle of P and R processes. Although over short time scales nutrient content in the euphotic zone is more dependent on photosynthesis than on respiration, its trend also portrays the metabolic history of the community and reflects the degree of steady-state conditions. Fig. 9 presents the concurrent variation of euphotic zone integrated values of oxygen saturation, nitrate concentration and $\mathrm{NCPeu}$. Both $\mathrm{O}_{2}$ saturation and nitrate concentration in the euphotic zone showed very similar annual trends, although sometimes slightly delayed (especially $\mathrm{O}_{2}$ ) with respect to NCPeu. As expected, these variables reflected the history of community metabolism better than NCP, as seen in April 1994 (aged spring bloom offshore) or during upwellings. In June 1994 the recent coastal upwelling of deep water generated a sharp increase in nitrate concentration and NCP, but no change in oxygen saturation was observed until 1 mo later, when a marked decrease of nitrate content was also evident. On the contrary, dur- 

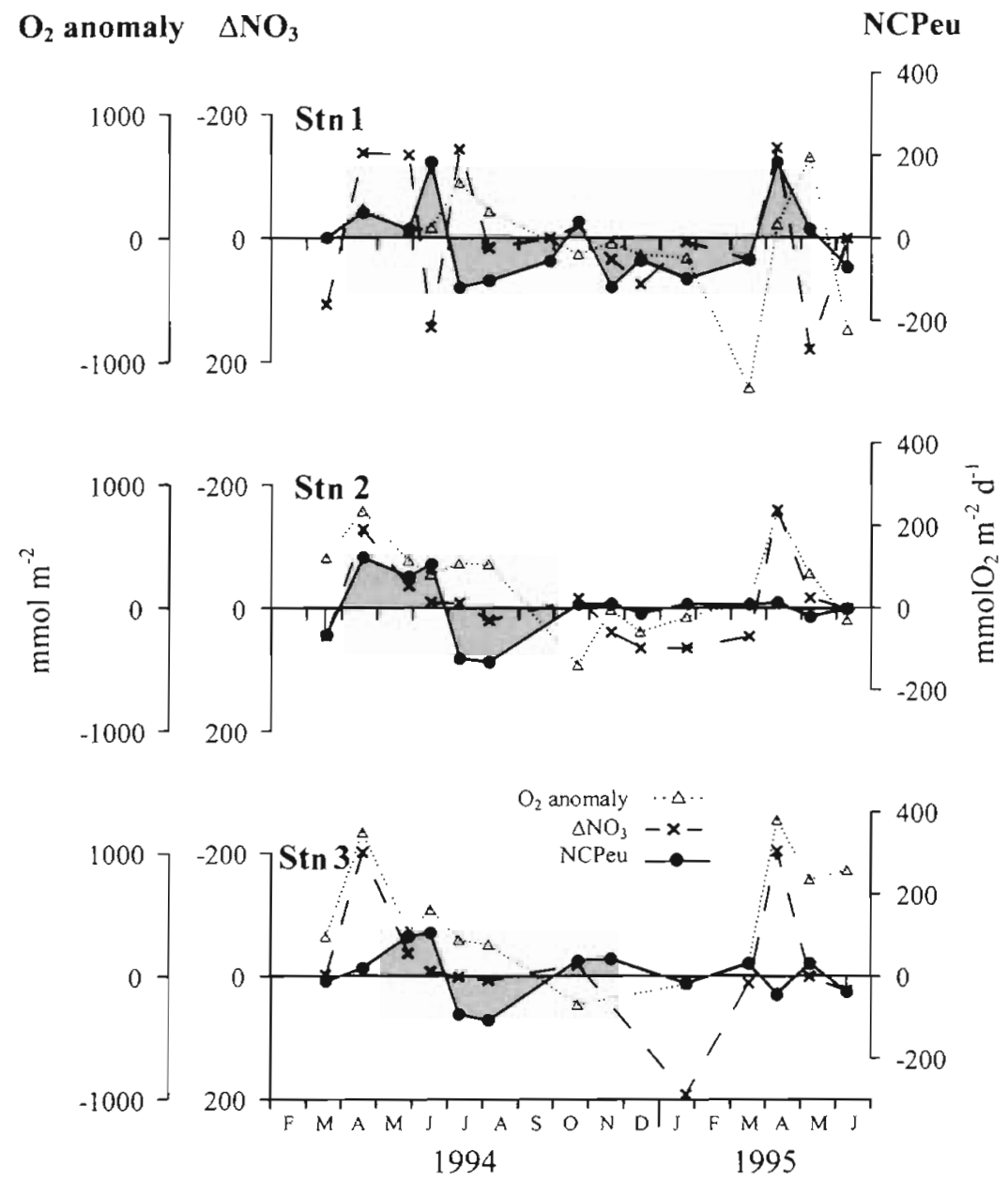

Fig. 9. Temporal variation in oxygen anomaly $\left(\mathrm{mmol} \mathrm{O}_{2} \mathrm{~m}^{-2}\right.$ of difference with respect to the concentration of saturation) and monthly increase in $\mathrm{NO}_{3}$ content $\left(\Delta \mathrm{NO}_{3}\right)$ in the euphotic zone at the 3 sampled stations. Temporal variation in NCPeu is shown superimposed for comparison

ing the aged upwelling in April 1995, $\mathrm{O}_{2}$ increase and nitrate decrease were not only concurrent to NCP increase, but also traced the offshore extension of the upwelling plume. This delay in the signal validates the use of the comparison between NCP and $\mathrm{O}_{2}$ saturation and nitrate content in the euphotic zone in order to detect non-sampled hydrographic and/or microbiological events. It is worth noting that throughout the summer, while DR greatly exceeded GP, $\mathrm{O}_{2}$ concentration remained oversaturated at the 3 sampled stations, but no trace of significant upwelling could be found

Therefore evidence suggests that the sampled annual cycle of NCP reasonably represents the community metabolism throughout the period of study at the 3 stations. Furthermore, with the exception of some situations (e.g. upwellings), it is not necessary to consider advection in order to explain the chemical conditions

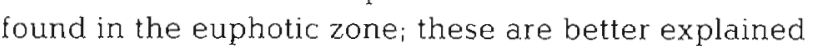

by biological activity within that layer i.e. steady-state conditions prevailed during the period of study. In fact, the sum of monthly changes of nitrate content in the euphotic layer from March 1994 to March 1995 was only $-48,+40$ and $-60 \mathrm{mmol} \mathrm{m} \mathrm{m}^{-2} \mathrm{yr}^{-1}$ at Stn 1 , Stn 2 and Stn 3 , respectively.

\section{DISCUSSION}

If the seasonal cycle of atmospheric $\mathrm{O}_{2}$ is caused by the temporal uncoupling in organic matter production and consumption in the sea (Keeling \& Shertz 1992, Pomeroy \& Wiebe 1993, Bender et al. 1996, Sherr \& Sherr 1996), the seasonal evolution of NCP must echo its trend. The seasonal and spatial distributions (vertical and horizontal) of production and respiration rates (together with those of nutrient and oxygen concentrations, and phytoplankton biomass) determined in this study clearly show the linkage in $\mathrm{P}$ and $\mathrm{R}$ through the exchange of local surpluses of organic matter, as well as the importance of terrigenous influence. Although the vertical scale was not sufficient to study the final fate of organic matter produced during several net autotrophic periods (e.g coastal upwelling), the horizontal scale considered was enough to provide a fair representation of trophic shifts and, hence, to study the time scales of interaction between autoand heterotrophic processes. Moreover, the verification of the prevalence of steady-state conditions, when the whole period and region of study are considered, will allow the interpretation of NCP data within a biogeochemical context.

\section{Seasonal variation of $P / R$ balance}

In this study a strong seasonal pattern was observed for both $\mathrm{O}_{2}$ production and consumption rates. A similar pattern of primary production rates, coupled to vertical stability transitions in the water column, has been described before in this region (e.g. Fernández \& Bode 1991). The highest temporal and vertical variability in $P$ rates was found at the coastal station, where more than $60 \%$ of total GP measured during 16 mo occurred at the surface layer, and was directly related to 
episodic coastal upwelling $(38 \%$ of total coastal euphotic zone GP). However, offshore productive periods were more related to the seasonal cycle of stratification and mixing, lasted longer, and were not dominated by surface processes. This highlights the importance of measuring $\mathrm{P}$ and $\mathrm{R}$ rates in subsurface layers in order to properly estimate the trophic balance of the community.

The range of DR rates was similar at the 3 stations studied. Also the seasonal trends, characterised by post-bloom and summer maxima, were similar except in winter, when high DR rates were only measured at the coastal station. Low phytoplankton biomass and activity, together with strong vertical mixing, suggest that high winter DR rates might be related to the consumption of allochthonous organic matter. Several processes may produce a winter increase of organic matter discharge to the coastal zone, e.g. the increase in flow and organic matter content of rivers (typically, lower salinity was found during the winter near the coast, ca 35.48, than offshore, ca 35.54), the seasonal breakage of macroalgae or the resuspension of settled material from the sediment.

Except during the winter at Stn 1, the pattern of $P / R$ balance was relatively uniform in the region, being characterised by a spring to summer transition from auto- to heterotrophy, which agrees with the results reported in previous studies (e.g. Rowe et al, 1986, Pomeroy \& Wiebe 1993, Blight et al. 1995, Griffith \& Pomeroy 1995). Diverse processes have been postulated as causing this pattern, mainly depending on the observed degree of coupling between auto- and heterotrophic metabolism of the community, i.e. depending on the periodicity and length of the different phases. In our study, the coincidence of the highest rates of primary production with phases of low total respiration, and the absence of a relationship between chl a concentration and DR rate, point to a low phytoplanktonic contribution to DR rates. Assuming phytoplankton respiration to be 10 to $15 \%$ of gross production (Setchell \& Packard 1979), the contribution of non-phytoplanktonic respiration to total measured respiration rate, over an annual scale, would be $87 \pm$ $2.1 \%, 83 \pm 3.6 \%$ and $81 \pm 2.9 \%$ for $\operatorname{Stn} 1$, Stn 2 and Stn 3 , respectively.

At coastal waters off North Wales, Blight et al. (1995) found a short (ca $3 \mathrm{wk}$ ) heterotrophic phase immediately after a Phaeocystis sp. bloom. The observed lag of about 2 wk between GP and DR maxima, as well as the lack of a relationship between total respiration and temperature (as is the case in the present study) led these authors to explain the auto-heterotrophy transition in terms of delayed consumption of high molecular weight dissolved organic matter (DOM), which had accumulated after Phaeocystis sp. growth. This conclu- sion is consistent with the results obtained in other studies, showing a strong relationship, sometimes slightly delayed, between microbial heterotrophic activities and primary production (Simon \& Tilzer 1987. Kirchman et al. 1991, 1994). This explanation would subscribe, as a special case given the slow processing of some high molecular weight DOM constituents, models of the regulation of bacterial activity by substrate availability (e.g. Cole et al. 1988, Wright 1988, Kirchman 1990).

Other authors (Pomeroy et al, 1991, Kirchman et al. 1993, Pomeroy \& Wiebe 1993, Sampou \& Kemp 1994, Shiah \& Ducklow 1994, Smith \& Kemp 1995) have attributed the seasonal variation in microbial respiration to the combined effect of temperature and substrate availability on heterotrophic bacterial metabolism. Experiments carried out with bacteria growing under a matrix of temperatures and substrate concentrations (Pomeroy et al. 1991, Wiebe et al. 1992, 1993) have shown a non-linear response of growth rate, with high $Q_{10}$ values ( $>10$ ) near the combination of minima temperature and substrate concentration. Temperature, then, appears to produce a marked effect on bacterial activity at the low substrate concentrations usually found in the ocean, while at high concentrations such an effect is considerably reduced. Pomeroy \& Wiebe (1993) attributed the observed shift from winterspring autotrophy to summer-autumn heterotrophy to the delay in the consumption of organic matter produced during the spring phytoplankton bloom until phytoplankton cell lysis or zooplankton excretion, defecation and sloppy feeding produced areas of high DOM concentration. In any case, a high bacterial contribution to total respiration has been frequently documented (see e.g. reviews by Williams 1981, Fuhrman 1992 and Sherr \& Sherr 1996), emphasizing the important role played by the regulation of bacterial activity on the seasonality of P/R balances (Pomeroy \& Wiebe 1993, Sherr \& Sherr 1996).

In this study, the summer heterotrophic phase $(2$ to $3 \mathrm{mo}$ ) was considerably longer than previously reported in the literature. It has already been mentioned that steady-state prevailed during this study, at least in the oceanic region. Nevertheless, there still exists the possibility that the observed long heterotrophic phase could be the result of the coincidence of summer samplings with short heterotrophic periods following non-sampled phases of high productivity. The comparison between NCPeu and $\mathrm{O}_{2}$ saturation and nutrient content in the euphotic zone allows the tracing of significant upwelling events. The observed trends of these variables (see Fig. 9) suggest that a significant event did not take place during the summer (apart from that in June 1994), and in any case suggest that the measured high DR rates did not derive from 
the consumption of recently synthesised organic matter. This could only happen in the auto-heterotrophy transition observed between June and July 1994. However, considering the euphotic zone of the 3 stations, the negative NCP value registered in July would correspond to $90 \%$ of the positive value of June, which seems too high to result from direct consumption. An aiternative explanation for the high DR measured during summer at every station could be the import of organic matter from adjacent marine regions or land This is difficult to sustain, as a similar heterotrophic balance was observed at the 3 stations and during 2 to 3 consecutive months; moreover, the strong water column vertical stability, and the presumably low organic matter discharge from land during the summer, all point to a reduced allochthonous influence. Once the suggestion of rapid consumption of imported or recently synthesised organic matter has been discredited, the only possible explanation for the heterotrophic balance throughout the summer is a delayed consumption of organic matter previously synthesised in the region.

Accumulation of DOM during the final phases of phytoplankton blooms has been frequently reported (e.g. Brockman et al. 1983, Norrman et al. 1995, Smith et al. 1995). Several investigations have also shown active bacterial consumption of the recently produced DOM (Lignell 1990, Kirchman et al. 1991, Smith et al. 1995). In our study, low DR rates measured in shelf waters in April 1994, when high phytoplankton biomass and active algal growth were registered (Figs. 3 \& 7), would be related to the delay in DOM accumulation, a necessary condition for activating bacterial growth at the relatively low temperature of spring water (Pomeroy \& Wiebe 1993). Meanwhile, in oceanic waters, where bloom decay was presumed, the observed increase of DR rates (Fig. 7) would reflect the rapid consumption of accumulated labile DOM. Hence, the observed enhancement in DR rates would correspond to the short heterotrophic phase often described after spring blooms (e.g. Blight et al. 1995), although the uncoupling between $P$ and $R$ could be a simple result of low temperature, and not necessarily of the semi-refractory nature of produced DOM. A similar process may explain the very low DR rates in recent upwellings and their offshore increase following the export and sinking of biomass, especially in late phases (compare April 1994, recent upwelling, with June 1995, aged upwelling, in Fig. 7. See also Fig. 3)

The control of heterotrophic activity by the interaction between substrate availability and temperature may also produce a decrease of $D R$ rates before the complete exhaustion of DOM, allowing the permanence in the euphotic zone of a surplus of non-con- sumed DOM (e.g. Pomeroy \& Wiebe 1993, Sherr \& Sherr 1996). Indeed, 1 mo after the spring bloom, although elevated GP remained in the euphotic zone, DR rates decreased to winter levels (see Fig. 7). The summer increase in water temperature would permit. the bacterial heterotrophic activity to increase at relatively low substrate concentrations, allowing the consumption of DOM not utilised during spring, and producing the observed increase in DR rates.

\section{Seasonal compensation of production and respira- tion processes is a characteristic of the dynamics of pelagic ecosystem in temperate seas}

The seasonal cycle of microbial net metabolism observed in the present study has greater amplitude and significance than usually reported in the literature; this derives from the spatial and temporal scales considered. First, the importance of measuring $\mathrm{P}$ and $\mathrm{R}$ rates within the whole euphotic zone, in order to adequately describe the trophic status of the system, has been shown (see also Williams 1998). Second, the length of the heterotrophic phase is greater than the delay of 2 to $3 \mathrm{wk}$ for the consumption of organic matter produced during spring blooms (e.g. Blight et al. 1995). Third, the observed coast-ocean patterns of seasonal variability suggest that the significance of the summer heterotrophic phase goes beyond the consumption of recently synthesised or allochthonous organic matter (e.g. Satta et al. 1996). The results presented in this paper strongly support the existence of a seasonal uncoupling in the processes of production and consumption of organic matter in the euphotic zone, emerging from the trophic dynamics of the pelagic ecosystem (e.g. Pomeroy \& Wiebe 1993, Griffith \& Pomeroy 1995, Sherr \& Sherr 1996). Specifically, it would ultimately derive from the physical control of planktonic primary production, which results in the coincidence of high primary production rates with relative low water temperatures, and from the regulation of heterotrophic bacterial activity by the interaction between temperature and substrate availability.

The explanation given above for the seasonality in $\mathrm{P} / \mathrm{R}$ balances implies the existence of an heterotrophic succession (see also reviews by Pomeroy \& Wiebe 1993 and Sherr \& Sherr 1996) in which, after rapid consumption of labile DOM (Riemann \& Søndergaard 1984, Chen \& Wangersky 1996), accumulated after the spring bloom (Kirchmann et al. 1991, Norman et al. 1995, Smith et al. 1995), a decrease of bacterial activity would be caused by low water temperature (Pomeroy et al. 1991, Wiebe et al. 1992, 1993, Shiah \& Ducklow 1994), thus allowing the permanence in the water column of a certain amount of DOM (both labile and 
refractory, both accumulated during the winter and produced after the spring bloom) (Carlson et al. 1994). This DOM would be progressively consumed when the increase in water temperature allowed the utilisation of both low concentrations of substrate and semirefractory compounds, giving rise to low bacterial growth efficiency (Kroer 1993) and, consequently, to elevated DR rates (Hopkinson et al. 1989). The preference for consumption of labile and/or N-rich DOM (Kirchmann 1990, Chen \& Wangersky 1996) would generate a progressive increase in the proportion of semi-refractory and high $\mathrm{C} / \mathrm{N}$ ratio compounds in the DOM. Hence, as high DR rates and a net heterotrophic balance remain until the end of the summer, a bacterial (specific or metabolic) succession from bacteria rapidly consuming labile DOM to the exoenzymatic degradation of semi-refractory and high $\mathrm{C} / \mathrm{N}$ ratio DOM (see e.g. Azam et al. 1994) would be expected.

The described amplitude of the seasonal offset of $P / R$ balances alone can explain the observed cycles of oxygen saturation and nutrient content in the euphotic zone (see Fig. 9), as well as the seasonal cycle of oxygen anomaly in middle and low latitudes (Najjar \& Keeling 1997), and, of greater significance, the atmospheric oxygen cycle described by Keeling \& Shertz (1992) and Bender et al. (1996). The air-sea $\mathrm{O}_{2}$ fluxes associated with the seasonal cycle in atmospheric $\mathrm{O}_{2}$ 'are linked to the rate at which organic material is produced and exported from the euphotic zone' (Keeling $\&$ Shertz 1992). In the northern hemisphere these data show a winter minimum and a late summer maximum which are consistent with the cycles of net production and upper ocean ventilation and with the idea of a temporal offset in organic matter production and consumption in the sea (Pomeroy \& Wiebe 1993, Sherr \& Sherr 1996). As stressed by Six \& Maier-Reimer (1996), 'atmospheric oxygen data provide an independent test for marine biota models. It is a unique quantity that gives information about net carbon production in the plankton community'. From the seasonal variation in atmospheric $\mathrm{O}_{2}$, Keeling \& Shertz (1992) estimated a spring ocean net production of organic carbon of ca $48 \mathrm{~g} \mathrm{C} \mathrm{m}^{-2}$. Similarly, Bender et al. (1996) calculated a seasonal net production of $60 \mathrm{~g} \mathrm{C} \mathrm{m}^{-2}$ for the southern hemisphere. Independently, Sambrotto et al. (1993) estimated, from the seasonal dissolved inorganic carbon deficit in the euphotic zone, a seasonal net production in the North Atlantic of $48 \mathrm{~g} \mathrm{C} \mathrm{m}^{-2}$ If a photosynthetic quotient of 1.3 (Laws 1991) is applied to the results of seasonal oxygen $P / R$ balance in the present study, NCPeu during the spring autotrophic phase would range from $46 \mathrm{~g} \mathrm{C} \mathrm{m}^{-2}$ at $\operatorname{Stn} 1$ to $72 \mathrm{~g} \mathrm{C} \mathrm{m}^{-2}$ at Stn 2 . This coincidence, both in the trends and absolute values, constitutes exceptional and independent confirmation of the idea that the long-term compensation of the seasonal $\mathrm{P} / \mathrm{R}$ imbalances is an intrinsic process of the pelagic ecosystem, at least in temperate seas.

The consideration of such a process as a constituent of system dynamics has profound implications for the interpretation of trophic organisation and the calculation of new production from nitrate uptake. For instance, if summer heterotrophy is sustained by the excess production of the spring, then the processes of recycling during the summer would not only represent a loop of local production, but also, to some extent, a source of new nutrients at the scales usually considered for estimating new production. On the other hand the quantification of the maximum removable biomass for system integrity will only be possible at temporal and spatial scales comprising the connection between auto- and heterotrophic subsystems.

\section{Annual net $P / R$ balances}

If the maintenance of the system during heterotrophic phases relies upon the consumption of the surplus of organic matter produced during preceeding autotrophic phases, then the annual net balance of the processes of production and consumption of organic matter must approach zero when steady-state conditions prevail, conditions that, in this study, tended to predominate towards the ocean.

Both the calculated values of annual $P / R$ balance and, of greater significance, the coast-ocean trend of that balance, indicate that no surplus of produced organic matter, available to export, exists in the euphotic zone over an annual scale. That is, the fate of organic matter synthesised on the shelf seems to be oxidation in situ rather than export to ocean depths. This coincides with the results of several studies which stress the importance of microbial consumption of organic matter (e.g. Rowe et al. 1986, Biscaye et al. 1994), and seems to be a result of the seasonal compensation of $\mathrm{P}$ and $\mathrm{R}$ derived from the processes controlling phytoplankton growth and microbial heterotrophic activity in temperate seas (Griffith \& Pomeroy 1995). Only certain processes (e.g. upwelling) which separate the system from steady-state, allow the export of a significant amount of organic carbon.

The recognition of the time and space scales relevant for the linkage between production and respiration processes in the sea is germane in order to ascertain the trophic status of the ocean. As pointed out by Smith \& Hollibaugh (1997) the definition of the trophic status' of an ecosystem from NCP 'carries with it a condition (usually not explicitly stated and often ignored) of the time span over which the inferred trophic status applies'. The present debate about the trophic status of the ocean (e.g. del Giorgio et al. 1997, Geider 1997, 
Duarte \& Agusti 1998, Williams 1998) is based on the accumulation of local measurements of either a net heterotrophic or a net autotrophic balance. This assumes the prevalence of steady-state conditions during sampling, i.e. that a temporal or spatial linkage between $P$ and $R$ is not significant, beyond 'a very limited separation in time (5 to $10 \mathrm{~d}$ or less) between the 2 phases - with no protracted period of high heterotrophy following the autotrophic bloom' (Williams 1998). Although both del Giorgio et al. (1997) and Duarte \& Agustí (1998) explained the net heterotrophy of unproductive regions as a result of temporal or spatial organic matter import, the data sets they used to derive their conclusion are biased, as no consideration is made of the scales over which the measured trophic statuses apply. The results of the present study indicate that an appreciation of the spatial and temporal scales at which the trophic dynamics of the pelagic ecosystem function is a priority, as only then may the determination of the balance between production and respiration help to elucidate the trophic status of the ocean

Acknowledgements. This study was undertaken as part of CICYT's AMB 92/0834 project, with additional support from the IEO's Programa 1007. P.S. was supported by a PFPI grant from the Ministerio de Educación y Ciencia and a grant from the Universidad de Oviedo within the European Commission project CE-96-MAS3-CT-0060. This paper was written while P.S. was funded by an EU TMR Marie Curie Research Training Grant (ERBFMBICT972700). Comments and support from C. Robinson are much appreciated. We also thank all the colleagues in the Universidad de Oviedo, and the captain and crew of 'José Rioja', for their support and hard work at sea, C. Fernández for her assistance with figures and Ángel LópezUrrutia for advice on statistics. E. Cabal helped with chl $a_{\text {, }}$ and R. González-Quirós and M. Quevedo provided hydrographic data. We appreciate the comments of 2 anonymous referees, which improved the manuscript.

\section{LITERATURE CITED}

Azam F, Smith DC, Steward GF, Hagström \& (1994) Bacteriaorganic matter coupling and its significance for oceanic carbon cycling. Microb Ecol 28:167-179

Bender M, Ellis T, Tans P, Francey P, Lowe D (1996) Variability in the $\mathrm{O}_{2} / \mathrm{N}_{2}$ ratio of southern hemisphere air: implications for the carbon cycle. Global Biogeochem Cycles 10: $9-21$

Biddanda B, Opsahl S, Benner R (1994) Plankton respiration and carbon flux through bacterioplankton on the Louisiana shelf. Limnol Oceanogr 39:1259-1275

Biscaye PE, Flagg CN, Falkowski PG (1994) The shelf edge exchange processes experiment, SEEP-II: an introduction to hypotheses, results and conclusions. Deep-Sea Res II $41(2 / 3): 231-252$

Blight SP, Bentley TL, Lefèvre D. Robinson C. Rodrigues $R$, Rowlands J, Williams PJleB (1995) Phasing of autotrophic and heterotrophic plankton metabolism in a temperate coastal ecosystem. Mar Ecol Prog Ser 128:61-75
Botas JA, Fernández E, Bode A, Anadón R (1990) A persistent upwelling off the central Cantabrian Coast (Bay of Biscay). Estuar Coast Shelf Sci 30:185-199

Brockmann UH, Ittekot V, Kattner G, Eberlein K, Hammer KD (1983) Release of dissolved organic substances in the course of a phytoplankton bloom. In: Sünderman J, Lenz W (eds) North Sea dynamics. Springer-Verlag, Berlin, p $530-548$

Carlson CA, Ducklow HW, Michaels AF (1994) Annual flux of dissolved organic carbon from the euphotic zone in the northwestern Sargasso Sea. Nature 371:405-408

Chen W, Wangersky PJ (1996) Rates of microbial degradation of dissolved organic carbon from phytoplankton cultures. I Plankton Res 18(9):1521-1533

Cole JJ, Findlay S, Pace ML (1988) Bacterial production in fresh and saltwater ecosystems: a cross-system overview. Mar Ecol Prog Ser 43:1-10

del Giorgio PA, Cole JJ, Cimbleris A (1997) Respiration rates in bacteria exceed phytoplankton production in unproductive aquatic systems. Nature 385:148-151

Duarte $\mathrm{C}_{1}$ Agustí $\mathrm{S}$ (1998) The $\mathrm{CO}_{2}$ balance of unproductive aquatic ecosystems. Science 281:234-236

Eppley RW (1989) New production: history, methods, problems. In: Berger WH, Smetacek VS, Wefer G (eds) Productivity of the ocean: present and past. Report of the Dahlem. Workshop on productivity of the ocean: present and past, Berlin 1988, April 24-29. Wiley Interscience Publications, Chichester, p 85-97

Fernández E, Bode A (1991) Seasonal patterns of primary production in the central Cantabrian Sea (Bay of Biscay). Sci Mar 55(4):629-636

Fernández E, Bode A, Botas A, Anadón R (1991) Microplankton assemblages associated with saline fronts during a spring bloom in the central Cantabrian Sea: differences in trophic structure between water bodies. J Plankton Res 13:1239-1256

Fernández E, Cabal J, Acuna J, Bode A, Botas A, García-Soto C (1993) Plankton distribution across a slope currentinduced front in the southern Bay of Biscay. J Plankton Res 15:619-641

Fuhrman J (1992) Bacterioplankton roles in cycling of organic matter: the microbial food web. In: Falkowski PG, Woodhead AD (eds) Primary productivity and biogeochemical cycles in the sea. Plenum Press, New York, p 361-383

Geider RG (1997) Photosynthesis or planktonic respiration? Nature 388:132

Grasshoff K, Ehrhardt M, Kremling (1983) Methods of seawater analysis, 2nd edn. Verlag Chemie, Weinheim

Griffith PC, Pomeroy LR (1995) Seasonal and spatial variations in pelagic community respiration on the southeast. ern US continental shelf. Cont Shelf Res 15(7):815-825

Holligan PM (1992) Do marne phytoplankton influence global climate? In: Falkowski PG, Woodhead AD (eds) Primary productivity and biogeochemical cycles in the sea. Plenum Press, New York, p 487-501

Hopkinson CS Jr, Sherr B, Wiebe WJ (1989) Size fractionated metabolism of coastal microbial plankton. Mar Ecol Prog Ser 51:155-166

Iriarte A, de Madariaga I, Diez-Garagarza F, Revilla M, Orive E (1996) Primary plankton production, respiration and nitrification in a shallow temperate estuary during summer. J Exp Mar Biol Ecol 208:127-151

Jahnke RA, Craven DB (1995) Quantifying the role of heterotrophic bacteria in the carbon cycle: a need for respiration rate measurements. Limnol Oceanogr 40(2): $436-441$

Keeling RF, Shertz SR (1992) Seasonal and interannual varia- 
tions in atmospheric oxygen and implications for the global carbon cycle. Nature 358:723-727

Kirchman DL. (1990) Limitation of bacterial growth by dissolved organic matter in the subarctic Pacific. Mar Ecol Prog Ser 62:47-54

Kirchman DL, Suzuki Y, Garside C, Ducklow HW (1991) High turnover rates of dissolved organic carbon during a spring phytoplankton bloom. Nature 352:612-614

Kirchman DL, Keil RG, Simon M, Welschmeyer NA (1993) Biomass and production of heterotrophic bacterioplankton in the oceanic subarctic Pacific. Deep-Sea Res I 40(5):967-988

Kirchman DL, Ducklow HW, McCarthy JJ, Garside C (1994) Biomass and nitrogen uptake by heterotrophic bacteria during the spring phytoplankton bloom in the North Atlantic Ocean. Deep-Sea Res I 41(5-6):879-895

Kroer N (1993) Bacterial growth efficiency on natural dissolved organic matter. Limnol Oceanogr 38:1282-1290

Krstulovic N, Pucher-Petkovic T, Solic M (1995) The relation between bacterioplankton and phytoplankton production in the mid Adriatic Sea. Aquat Microb Ecol 9:41-45

Laws EA (1991) Photosynthetic quotients, new production and net community production in the open ocean. DeepSea Res 38(1):143-167

Lignell R (1990) Excretion of organic carbon by phytoplankton: its relation to algal biomass, primary productivity and bacterial secondary productivity in the Baltic Sea. Mar Ecol Prog Ser 68:85-99

Lignell R, Heiskanen AS, Kuosa H, Gundersen K, KuuppoLeinikki P, Pajuniemi R, Uitto A. (1993) Fate of a phyto plankton spring bloom: sedimentation and carbon flow in the planktonic food web in the northern Baltic. Mar Ecol Prog Ser 1994:239-252

Maranoón E, Fernández E, Anadón R (1995) Patterns of macromolecular synthesis by natural phytoplankton assemblages under changing upwelling regimes: in situ observations and microcosms experiments. I Exp Mar Biol Ecol 188:1-28

Najjar RG, Keeling RF (1997) Analysis of the mean annual cycle of the dissolved oxygen anomaly in the World Ocean. J Mar Sys 55:117-151

Norrman B, Zweigel UL, Hopkinson CS, Fry B (1995) Production and utilization of dissolved organic carbon during an experimental diatom bloom. Limnol Oceanogr 40(5):898-907

Oudot C, Gerard R, Morin P, Gningue I (1988) Precise shipboard determination of dissolved oxygen (Winkler procedure) for productivity studies with a commercial system. Limnol Oceanogr 33:146-150

Pakulski JD, Benner R, Amon R, Eadie B, Whitledge T (1995) Community metabolism and nutrient cycling in the Mississippi River plume: evidence for intense nitrification at intermediate salinities. Mar Ecol Prog Ser 117:207-218

Pingree RD, Le Cann B (1990) Structure, strength and seasonality of the slope currents in the Bay of Biscay region. J Mar Biol Assoc UK 70:857-885

Pomeroy LR, Wiebe WJ (1993a) Energy sources for microbial food webs. Mar Microb Food Webs 7(1):101-118

Pomeroy LR, Wiebe WJ, Deibel D, Thompson RJ, Rowe GT, Pakulski JD (1991) Bacterial responses to temperature and substrate concentration during the Newfoundland spring bloom. Mar Ecol Prog Ser 75:143-159

Pomeroy LR, Sheldon JE, Sheldon WM Jr (1994) Changes in bacterial numbers and leucine assimilation during estimations of microbial respiratory rates in seawater by the precision Winkler method. Appl Envir on Microbiol 60:328-332

Quinones RA, Platt T (1991) The relationship between the fratio and the $P: R$ ratio in the pelagic ecosystem. Limnol Oceanogr 36(1):211-213
Riemann B, Sondergaard M (1984) Bacterial growth in relation to phytoplankton primary production and extracellular release of organic carbon. In: Hobbie JE, Williams PJleB (eds) Heterotrophic activity in the sea. Plenum Press, New York, p 530-548

Rowe GT, Smith S, Falkowski PG, Whitledge T, Theroux R, Phoel W, Ducklow H (1986) Do continental shelves export organic matter? Nature 342:559-561

Sambrotto RN, Savidge G, Robinson C, Boyd P, Takahashi T, Karl DM, Langdon C, Chipman D, Marra J, Codispoti L (1993) Elevated consumption of carbon relative to nitrogen in the surface ocean. Nature 363:248-250

Sampou P, Kemp WM (1994) Factors regulating plankton community respiration in Chesapeake Bay. Mar Ecol Prog Ser 110:249-258

Satta MP, Agustí S, Mura MP, Vaqué D, Duarte CM (1996) Microplankton respiration and net community metabolism in a bay on the NW Mediterranean coast. Aquat Microb Ecol 10(2):165-172

Setchell FW, Packard TT (1979) Phytoplankton respiration in the Peru upwelling. J Plankton Res 1(4):343-354

Sherr EB, Sherr BF (1996) Temporal offset in oceanic production and respiration processes implied by seasonal changes in atmospheric oxygen: the role of heterotrophic microbes. Aquat Microb Ecol 11:91-100

Shiah FK, Ducklow HW (1994) Temperature and substrate regulation of bacterial abundance, production and specific growth rate in Chesapeake Bay, USA. Mar Ecol Prog Ser 103:297-308

Simon M. Tilzer MM (1987) Bacterial response to seasonal changes in primary production and phytoplankton biomass in Lake Constance. J Plankton Res 9:535-552

Six KD, Maier-Reimer E (1996) Effects of plankton dynamics on seasonal carbon fluxes in an ocean general circulation model. Global Biogeochem Cycles 10(4):559-583

Smith DC, Steward GF, Long RA, Azam F (1995) Bacterial mediation of carbon fluxes during a diatom bloom in a mesocosm. Deep-Sea Res II 42(1):75-97

Smith EM, Kemp WM (1995) Seasonal and regional variations in plankton community production and respiration for Chesapeake Bay. Mar Ecol Prog Ser 116:217-231

Smith SV, Hollibaugh JT (1997) Annual cycle and interannual variability of ecosystem metabolism in a temperate climate embayment. Ecol Monogr 67(4):509-533

Smith SV, Mackenzie FT (1987) The ocean as a net heterotrophic system: implications from the carbon biogeochemical cycle. Global Biogeochem Cycles 1:171-183

Strickland JDH, Parsons TR (1972) A practical handbook of seawater analysis, 2nd edn. Bull Fish Res Board Can 167

Wiebe WJ, Sheldon WM Jr, Pomeroy LR (1992) Bacterial growth in the cold: evidence for an enhanced substrate requirement. tppl Environ Microbiol 58:359-364

Wiebe WJ, Sheldon WM Jr, Pomeroy LR (1993) Evidence for an enhanced substrate requirement by marine mesophilic bacterial isolates at minimal growth temperatures. Microb Ecol 25: 151-159

Williams PJleB (1981) A review of measurements of respiration rates of marine plankton populations. In: Hobbie JE Williams PJleB (eds) Heterotrophic activity in the sea Plenum Press, New York, p 357-389

Williams PJleB (1998) The balance of plankton respiration and photosynthesis in open oceans. Nature 394:55-57

Wright RT (1988) A model for short-term control of the bacterioplankton by substrate and grazing. Hydrobiologia 159(1):111-117 